\title{
Modeling of the Heat Exchange Process in the Cylinder of Diesel between the Fuel Circuit and the Air Charge
}

\author{
Dmitry Glazkov* and Viktor Odintsov \\ Baltic Fishing Fleet State Academy, Russia
}

Submission: December 18, 2017; Published: February 13, 2018

*Corresponding author: Dmitry Glazkov, Senior Lecturer, Baltic Fishing Fleet State Academy, Kaliningrad, Russia, Email: 2338697@gmail.com

\section{Short Communication}

Studies of the process of atomization of fuel by injectors of ICE showed [1,2] that oxygen and fuel in the jet are distributed unevenly. The value of the excess air factor in the fuel flare decreases from $0.8-0.9$ on its surface [3] to $0.15-0.25$ at its center [4], and the droplet sizes increase from a few microns to $0.1 \mathrm{~mm}$ and more. The maximum diameter of the fuel droplets corresponds to the diameter of the nozzle nozzles of the injector [5].

Therefore, combustion begins on the surface of the fuel jets [6], and it is the heat and mass exchange surface between the fuel injected into the engine cylinder and the surrounding air charge. Professor V.I. Odintsov [7] proposed to assign the surface of the fuel flare to the cyclic fuel supply (F/gf). With the purpose of revealing quantitative regularities of the change in the exponent F/g, a simulation was carried out when fuel was supplied through one nozzle aperture.

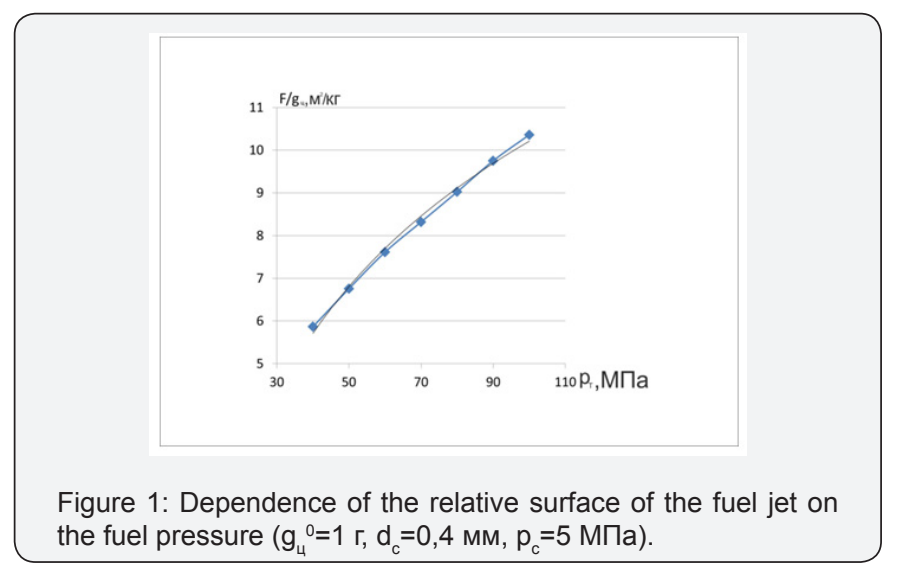

It has been established that with increasing fuel pressure at constant air-charge pressure and cyclic fuel supply, the surface of the fuel jet increases logarithmically Figure 1 with the confidence $\mathrm{R} 2=0.9994$ and an expression is obtained that relates the relative surface of the fuel jet to the parameters of the fuel supply process and the characteristics of the atomizer:

(F/gц0)эdсп-(F/gц0)пdсэ=0,6ln((dсп (Ртэ-Рсэ)/(dсэ (РтпРсп)) (1)

In expression (1), the following symbols are used: dc is the diameter of the nozzle aperture, gц0 is the cyclic fuel supply through one hole, $\mathrm{P}_{\mathrm{T}}$ is the fuel supply pressure, $\mathrm{P}_{c}$ is the air charge pressure. Parameters with the index «e» refer to the engine for which the quantities entering into the expression (1) are known, and the parameters with the index «p» to the engine being studied or projected [7]. Expression (1) can also be used to simulate the effect of changing the atomizer type, fuel pressure and air charge pressure on the development of the fuel flare when the technical condition of the engine changes and its fuel equipment is replaced [8]. The amount of heat transferred to the fuel cone during the processes of evaporation and mixture formation can be determined according to the Newton-Richman law:

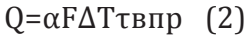

where $\alpha$ is the heat transfer coefficient from the air charge to the fuel cone, $\mathrm{BT} /\left(\mathrm{M}^{2} . K\right) ; \mathrm{F}$ - the surface area of the fuel cone, $\mathrm{M}^{2}, \Delta \mathrm{T}=$ Тц-Ттопл - the difference between the average mass temperatures of air charge and fuel, К; твпр - duration of injection, sec. As is known, in the absence of combustion, the fraction of heat transferred to the injected fuel with radiation does not exceed $1.5 \%$. But with the appearance of a flame, that is, during combustion during the fuel supply period, the radiant heat flow between the flame front and the fuel drops can be significant. The radiant component of the heat flux from the flame front to the fuel droplets can be calculated using the Stefan-Boltzmann law:

$$
\mathrm{Q}_{2}=\varepsilon \mathrm{FC}_{0}\left(\left(\mathrm{~T}_{\max } / 100\right)^{4}-\left(\mathrm{T}_{\text {топл }} / 100\right)^{4}\right)
$$


where $\varepsilon=0,8 \ldots 0,9$ - degree of blackness of the flame, $F$ radiation-receiving surface of fuel droplets, $\mathrm{C}_{0}=5,67 \mathrm{BT} /\left(\mathrm{M}^{2}\right.$. $\mathrm{K}^{4}$ ) - the emission constant of an absolutely black body, $\mathrm{T}_{\text {max }}$ maximum flame temperature, $\mathrm{T}_{\text {топл }}$ - temperature of fuel drops. Calculation of the heat transfer coefficient $\alpha$ is the subject of another article.

\section{Conclusion}

1. A dependence is presented that reflects the effect of the diameter of the nozzle openings and the differential pressure on the injection on the relative heat exchange surface between the fuel jet and the air charge.

2. The expression for modeling the influence of operating factors on the coefficient of heat transfer from the working fluid to the fuel jet will be presented in the next article.

\section{References}

1. Brose D (1969) Combustion in piston engines. Mechanical Engineering pp. 248
2. Semenov BN, Lazurko VP, Kireichev GA (1975) Some results of the investigation of the temperature fields of the flame of a sprayed fuel in a volume and in its interaction with a wall. 68: 27-35.

3. Kavtaradze RZ (2008) Theory of reciprocating engines. In: Bauman NE (Ed.), Special chapters. Textbook for universities, Izd. MSTU, Moscow, Russia, pp. 719.

4. Lyshevsky AS (1971) Spraying of fuel in marine diesel engines. Shipbuilding pp. 248.

5. Gafurov RA, Glebov GA, Skvortsov YM (1997) Diagnosis of the structure of a non-stationary diesel fuel jet during cyclic injection by pulse holography. Bulletin of the KSTU p. 5-9.

6. Svirido Y (1972) Mixing and combustion in diesel engines. Mechanical Engineering pp. 224.

7. Odintsov VI (2010) Working process of ship engines. Monograph.Kaliningrad, publishing house of the BFFSA, Russia, pp. 135.

8. Odintsov V, Polevoy VV, Sviridyuk NV (2017) Analysis of the process of heat exchange in marine ICE and methods of its modeling. Marine Intellectual Technologies, SPb, 3 (37): 80-84.
Your next submission with Juniper Publishers will reach you the below assets

- Quality Editorial service

- Swift Peer Review

- Reprints availability

- E-prints Service

- Manuscript Podcast for convenient understanding

- Global attainment for your research

- Manuscript accessibility in different formats ( Pdf, E-pub, Full Text, Audio)

- Unceasing customer service

Track the below URL for one-step submission https://juniperpublishers.com/online-submission.php 